\title{
Self limiting fetal bradycardia associated with maternal evidence of dengue and chikungunya virus co-infection: a case report
}

\author{
Alka Goel $^{1}$, Anupriya Narain ${ }^{2 *}$, Atul Goel ${ }^{3}$ \\ ${ }^{1}$ Department of Obstetrics and Gynecology, PGIMER and Dr. RML Hospital, New Delhi, India \\ ${ }^{2}$ Department of Obstetrics and Gynecology, MAMC and Lok Nayak Hospital, New Delhi, India \\ ${ }^{3}$ Department of Medicine, PGIMER and Dr. RML Hospital, New Delhi, India
}

Received: 13 February 2019

Accepted: 08 April 2019

*Correspondence:

Dr. Anupriya Narain,

E-mail: anupriyanarani@gmail.com

Copyright: ( ) the author(s), publisher and licensee Medip Academy. This is an open-access article distributed under the terms of the Creative Commons Attribution Non-Commercial License, which permits unrestricted non-commercial use, distribution, and reproduction in any medium, provided the original work is properly cited.

\begin{abstract}
Dengue and chikungunya infections are commonly encountered by the clinicians in a tropical country like India. We report this case to emphasize the rare manifestations of self-limiting intrapartum bradycardia in fetuses of chikungunya and dengue infected mothers. A primigravida at 32 weeks of gestation presented with history of fever for one day. The blood investigations were positive for both dengue and chikungunya virus infection. On the third day of fever, NST showed a low baseline fetal heart rate of 95 to 100 beats per minute but good beat to beat variability and three accelerations in 10 minutes. This pattern persisted for 48 hours. Although, the finding initially appeared alarming, the change in baseline heart rate of fetus was transient and self-limiting and recovered completely. Hence, a judicious approach and close fetal surveillance can avoid hasty decisions regarding an early termination of pregnancy.
\end{abstract}

Keywords: Bradycardia, Chikungunya, Dengue, Fetal, Intrapartum, Self-limiting

\section{INTRODUCTION}

Co-infections with arboviruses are not an unknown phenomenon in literature, but the arboviral co-infections during pregnancy and its fetal effects is very rare. ${ }^{1}$ This peculiar case study is being reported to highlight coinfection with dengue and chikungunya virus in a pregnant patient, who presented with fetal cardiac effects with fever. A thorough review of literature suggests that no such case has been reported previously. This is important because both viruses are known to target the cardiovascular system. Salgado et al have demonstrated heart and skeletal muscle as targets of dengue infection. ${ }^{2}$ The manifestation of acute infection of chikungunya virus is typical featuring high fever, headache, emesis, rash, myalgia and ar-thralgia. ${ }^{3}$ Various studies suggest that adverse effects of chikungunya on pregnancy are primarily encephalopathy. ${ }^{4}$ However, various cardiovascular effects have been reported in pa-tients of chikungunya which include tachycardia, irregular pulse, atrial and ventricular VPCs. ${ }^{5}$

\section{CASE REPORT}

A primigravida, married for 5 years and conceived after infertility treatment presented at 32 weeks of gestation with history of fever for one day. She was a booked patient and had regular ANC visits right from first trimester, and all her ANC visits had been normal till date.

Along with fever she complained of vomiting and dull lower abdominal pain, which was continuous. At admission, her LMP was 14 February 2017 with an EDD of 21 November 2017, her exact gestation period being 32 weeks and 2 days. 
Per-abdomen uterine height was 32 weeks and corresponded with the period of amenorrhea. Fetal heart rate was 144 beats per minute and regular. Her temperature at admission was $102^{\circ} \mathrm{F}$. On the second day after admission (third day of fever), Non stress test (NST) showed a low baseline fetal heart rate of 95 to 100 beats per minute but good beat to beat variability and four accelerations in 10 minutes (Figure 1). This pattern persisted for 48 hours. On the other hand, maternal pulse rate was 110-120 per minute. A doppler ultrasound done on 4th day of fever showed a brain sparing effect. Dengue NS1 antigen and IgM ELISA test for chikungunya were positive. Electrocardioram, Echocardiography, Hemogram and all other biochemical tests were unremarkable. As non-stress test showed satisfactory spontaneous accelerations, an informed decision to continue the pregnancy was taken.

Injection Betamethasone was administered in two divided doses 24 hours apart. Fetus was monitored with daily NST. After 48 hours, fetal heart rate spontaneously recovered to a baseline of 130 beats/minute and doppler flows became normal in the ultrasound repeated after one week. Fever lasted for a total duration of five days and the patient was discharged after the normal scan.

At 34 weeks gestation, she developed intrahepatic cholestasis of pregnancy with total bile acid of 19.8 $\mu \mathrm{mol} / \mathrm{l}$ and was administered ursodeoxycholic acid 300 mg twice a day. Subse-quently, her pregnancy continued uneventfully. She was induced at 37 weeks due to IHCP and delivered a healthy baby of $2.8 \mathrm{Kg}$ vaginally.

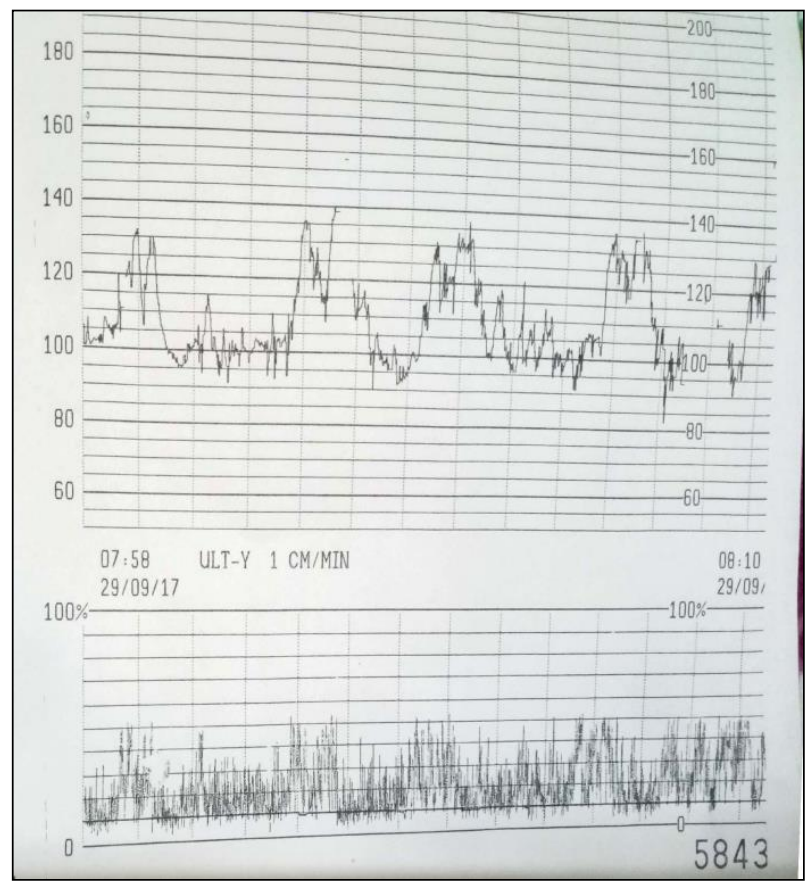

Figure 1: Non stress test showing fetal bradycardia with a baseline of $100 / \mathrm{min}$, good beat to beat variabilty and 4 accelerations in 10 minutes.

\section{DISCUSSION}

The risk of vertical transmission of chikungunya virus is well documented between $27.7-48.3 \%$, which increases to $50 \%$ with acute maternal viremia during delivery. ${ }^{6}$ Escobar et al, reported clinical manifestations of neonatal chikungunya including fever, irritability, rash and hyperalgesia syndrome. ${ }^{7}$ Diffuse limb edema, meningoencephalitis and bullous dermatitis were other rare manifestations. Encephalopathy in neonates has been associated with chikungunya virus as well as zika virus infections. . $^{4}$

Cardiac complications with dengue infection have been well documented in the paediatric literature. A recent study by Kumar et al reported myocarditis in a still born with an evidence of transplacental transmission of dengue infection from the mother. ${ }^{9}$ Another Interestingly, there is evidence of histopathological changes of fetal hypoxia in the placenta of newborn with dengue infected mothers. ${ }^{10}$ However, there is no evidence of infection of the human syntiotrophoblastic tissue by the chikungunya virus per se. ${ }^{11}$ Promphan et al, have reported sinus node dysfunction following dengue infection in a 13-year boy who developed bradycardia and hypotension. ${ }^{12}$ Thus, there is clear literary evidence of the cardiovascular effects of dengue and chikungunya infections. The authors are of the opinion that in all such cases, close fetomaternal surveillance and judicious approach is of utmost importance in the interest of both the mother and the fetus.

\section{Funding: No funding sources \\ Conflict of interest: None declared \\ Ethical approval: Not required}

\section{REFERENCES}

1. Villamil- Go`mez WE, et al. Zika, dengue, and chikungunya co infection in a pregnant woman from Columbia Int j Infect Dis. 2016 Oct;51:135-138.

2. Salgado DM, Eltit JM, Manfield K, César Panqueba DVM, Castro D, et al. Heart and skeletal muscle are targets of dengue virus infection. Pediatr Infect Dis J. 2010;29(3):238-42.

3. Bodenmann P, Genton B. Chikungunya: an epidemic in real time. Lancet. 2006;368(9531):258.

4. Ge' rardin $\mathrm{P}$, Barau $\mathrm{G}$, Michault $\mathrm{A}$, Bintner M, Randrianaivo H, Choker G, et al. Multidisciplinary prospective study of mother-to-child chikungunya virus infections on the island of La Re union. PLoS Med. 2008;5:e60.

5. Alvarez MF, Bolívar-Mejía A, Rodriguez-Morales AJ, Ramirez-Vallejo E. Cardiovas-cular involvement and manifestations of systemic chikungunya virus infection: A systematic review. F1000Res. 2017;6:390.

6. Torres JR, Falleriou-Arlant LH, Duenas L, PleitezNavarrete J, Salgado DM, Castillo JBD. Congenital and perinatal complications of chikungunya fever: a 
Latin American experience. Int $\mathbf{J}$ Infect Dis. 2016;51:85-8.

7. Escobar M, Neito AJ, Loaiza-Osorio S, Barona JS, Rosso F. Pregnant women hospitalized with chikungunya virus infection, Columbia 2015. Emer Infect Dis. 2017;23(11):1777-83.

8. Roze' B, Najioullah F, Signate A, Apetse K, Brouste $\mathrm{Y}$, Gourgoudou $\mathrm{S}$, et al. Zika virus detection in cerebrospinal fluid from two patients with encephalopathy, Martinique, February 2016. Euro Surveill. 2016;21.

9. Kumar D, Sanjeev RK. A rare manifestation pf congenital dengue infection. HK J Paediatr (new series). 2016;21:204-6.

10. Ribeiro CF, Lopes VGS, Brasil P, Pires ARC, Rohloff R, Nogueira RMR. Dengue infection in pregnancy and its impact on the placenta. Int $\mathrm{J}$ Infect Dis. 2017;55:109-12.
11. Couderc T, Chretien F, Schilte C, Disson O, Brigitte $\mathrm{M}$, Guivel-Ben-hassine $\mathrm{F}$ et al. A mouse model for chikungunya: young age and inefficient type-I interferon signalling are risk factors for severe disease. PLoS Pathog. 2008;4:e29.

12. Promphan W, Sopontammarak S, Pruekpraset P, Kajornwattankul W, Kongpattanayothin A. Dengue myocarditis. Southeast Asian J Trop Med Public Health. 2004;35(3):611-3.

Cite this article as: Goel A, Narain A, Goel A. Self limiting fetal bradycardia associated with maternal evidence of dengue and chikungunya virus coinfection: a case report. Int J Reprod Contracept Obstet Gynecol 2019;8:2103-5. 